\title{
An Electron Microscopic Study of the Antifertility Potential of Rosemary (Rosmarinus officinalis L.) in Male Albino Rats
}

\author{
Estudio de Microscopía Electrónica del Potencial Antifertilidad \\ del Romero (Rosmarinus officinalis L.) en Ratas Macho Albinas \\ "Rania A. Salah El-Din, **Abd El-Rahman El-Shahat \& *Rasha Ahmed Elmansy
}

EL-DIN, R. A. S.; EL-SHAHAT, A. E. \& ELMANSY, R. A. An electron microscopic study of the antifertility potential of Rosemary (Rosmarinus officinalis L.) in male albino rats. Int. J. Morphol., 30(2):666-672, 2012.

SUMMARY: The present work was aimed at studying the antifertility potential of the commonly used herb, rosemary in the male albino rats using electron microscopy as the method of investigation. Ethanolic extract of the rosmary prepared and administered orally in two different doses for a period of three months to the animals. At the end of the experiment animals were sacrificed and testes removed. Sections for the electrone microscopy prepared and changes were observed. The present results showed evident microscopic changes in the testis of the animals received higher dose of the drug. Most of the seminiferous tubules were compressed, having irregular basement membrane and devoid of any spermatogenic cells. The present work revealed a clear morphological evidence of the dose dependent antifertility potential of the rosemary in the male albino rats.

KEY WORDS: Antifertility potential; Rosemary; Rosmarinus officinalis L.; Electron microscopy; Male albino rats.

\section{INTRODUCTION}

Rosemary (Rosmarinus officinalis L.)(RO) is a commonly used plant for the remedy of various ailments in many parts of the world. Traditionally it is mostly used for relieving visceral muscle spasms in renal colic, menstrual pain, bronchial asthma and gastrointestinal colic. It also has some therapeutic value in the treatment of disorders like, peptic ulcers, inflammatory diseases, hepatotoxicity, atherosclerosis, ischemic heart disease, cataracts, and cancer (Valenzuela et al., 2004; Katerinopoulos et al., 2005).

The major constituents of this plant are caffeic acid and its derivatives such as rosmarinic acid (Herrero et al., 2005). These compounds have fibrinolytic and antioxidative activity (Ramírez et al., 2004; Nusier et al., 2007). Accumulating evidence suggests that the protective effects of RO against oxidative damage could be attributed to its anti-oxidative properties (Makino et al., 2002; Tseng et al., 1997). The anti-oxidant activity of RO could be attributed to its phenolic contents, namely protocatechuic acid (Wang et al., 2000) and anthocyanins (Liu et al., 2002; Tsai \& Huang, 2004). RO has also been reported to prevent or attenuate decrease in tissue anti-oxidant enzymes in different animal models and to provide cellular protection against oxidative stress (Prenesti et al., 2007; Amin \& Hamza, 2006). The essential action of RO essential oil is in stimulation of the nervous system under sympathetic control resulting in improved memorizing and concentrating abilities (Amin \& Hamza, 2005). Essential oil derived from rosemary has also shown an inhibitory effect on osteoclasts activity and increase bone density in vitro (Working et al., 1985). Besides these effects and longstanding valuable indications of rosenmary in traditional medicine, recently Nusier et al. have reported an antifertility effect of the ethanolic extract of the leaves of this plant in the males using rats as a mammalian model. Nusier et al. administered dietary rosemary to adult rats for a period of 63 days. They have reported a significant decreased in the sperm density and motility present in the cauda epididymidis and testes of the treated male rats.

The aim of the present work is to investigate the contraceptive potential of the orally ingested extract of RO leaves amongst the male rats using an electron microscopic approach.

\footnotetext{
* Department of Anatomy, Faculty of Medicine, Ainshamas University, Egypt.

** Department of Anatomy, Faculty of Medicine, Cairo University, Egypt.
} 


\section{MATERIAL AND METHOD}

Thirty adult male albino rats weighing 200- 250 gm were used in the present study. The animals were kept in the animal house in the Medical Research Center and Bilharizial Researches, Faculty of Medicine, Ain Shams University hospitals. Animals were housed in separate cages under conventional and controlled conditions with $12 \& 12$ light \&dark cycle at 23-250 C. The rats were maintained on standard laboratory diet with free access to water.

Preparation of Rosemary extract. Each $500 \mathrm{~g}$ of dried and grounded RO was refluxed in 2 liters of $70 \%$ ethanol at $60^{\circ}-70^{\circ} \mathrm{C}$ for 36 hours in a continuous extraction (soxhalet) apparatus. The ethanol extract was filtered and concentrated under reduced pressure at $60^{\circ} \mathrm{C}$ using a rotary evaporator. The net yield was $34 \mathrm{~g} / \mathrm{kg}$. (Purohit \& Daradka, 1999).

This material was then dissolved in distilled water and administered orally to rats at a concentration of 250 and $500 \mathrm{mg} / \mathrm{kg}$ body weight (1-ml volume) as single daily dose. Controls received $1 \mathrm{ml}$ of distilled water/day using same technique.

Experimental design. Animals were randomly divided into three equal groups each comprising of 10 rats.

Group I (Control): Rats received $1 \mathrm{ml}$ of distilled water for three months.

Group II: Rats received $250 \mathrm{mg} / \mathrm{kg}$ body weight RO for three months.

Group III: Rats received $500 \mathrm{mg} / \mathrm{kg}$ body weight RO for three months.

The animals were fed at laboratory chow and water ad libitum. All the animals were sacrificed at the end of experiment using light ether anesthesia. The scrotum of each animal was incised and testes were removed. For electron microscopic study, the removed testes were immersed in $2.5 \%$ buffered gluteraldehyde for 24 hours and then dehydrated in ascending grades of ethyl alcohol (50\%-70\%- 80\%- 90\%-100\%).

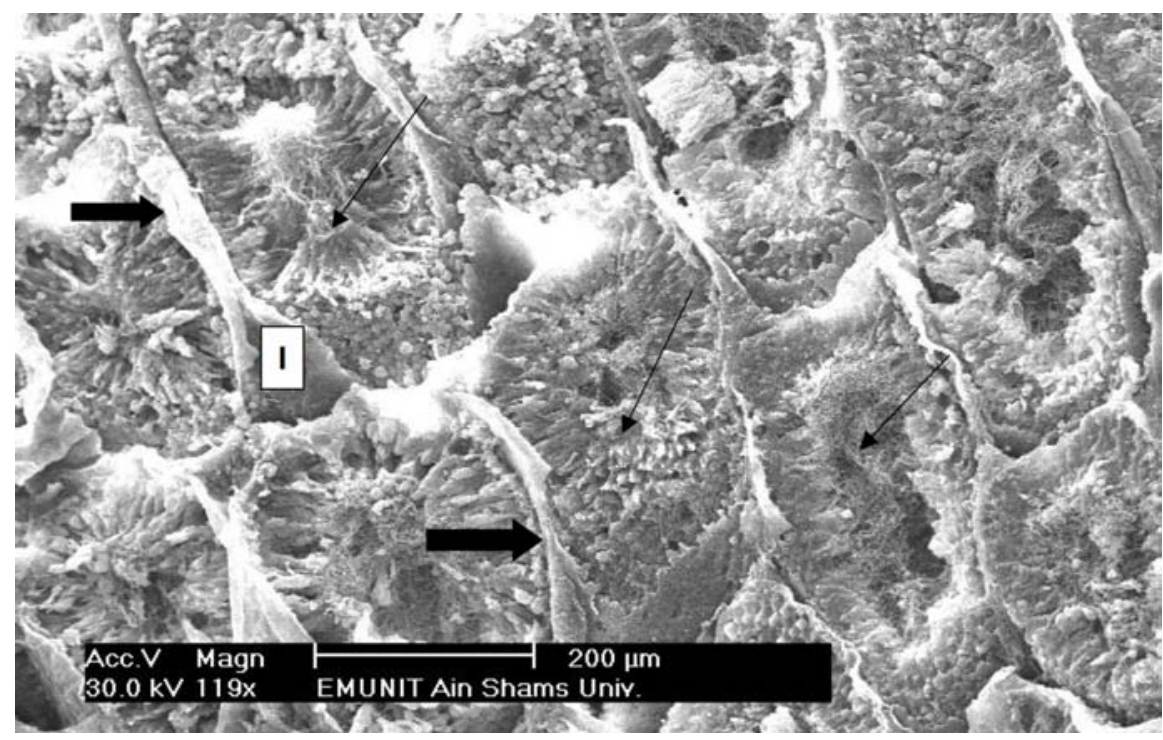

Fig. 1. Scanning electron micrographs of testicular sections of rats of the control group showing: seminiferous tubules (Thick arrow) with interstitial spaces (I) in between. Notice that their lumina are completely occupied by mature elongated spermatids (Thin arrows)(SEM x119).
The tissues were then further dehydrated in a mixture of $1: 1$ absolute alcohol and acetone $100 \%$ and then in $100 \%$ acetone twice; fifteen minutes for each. The specimens were then dried at critical point using liquid carbon dioxide in BALTEK CPD030 critical point dryer. The specimens were fixed on aluminum stubs and then sputter coated with gold using BALTEKSCD005. Some specimens were cut with freeze fracture after immersion in liquid nitrogen. The testes of all animals were examined using scanning electron microscope Philips XL30 (Robinson et al., 1987).

\section{RESULTS}

Scanning electron microscopic (SEM) examination of the testicular sections from the control group showed many seminiferous tubules with rounded, regular outlines. They were separated by narrow interstitial spaces (Fig 1) having all types of germ cells lying close to each other. Lumina of the tubules were completely occupied by the mature spermatids (Fig. 2). Each elongated spermatid exhibited an oval head and a single straight tail of uniform thickness facing towards the lumen (Fig. 3).

SEM sections of the testis from group II animals exhibit slight morphological changes compared to the control animals. All the spermatogenic cell types constituting the successive stages of sperma-togenesis were found to be present in the sections. The seminiferous tubules appeared with slightly irregular outlines (Fig.4). The lumina of most of the seminiferous tubules were occupied by mature elongated spermatids (Fig. 5). 

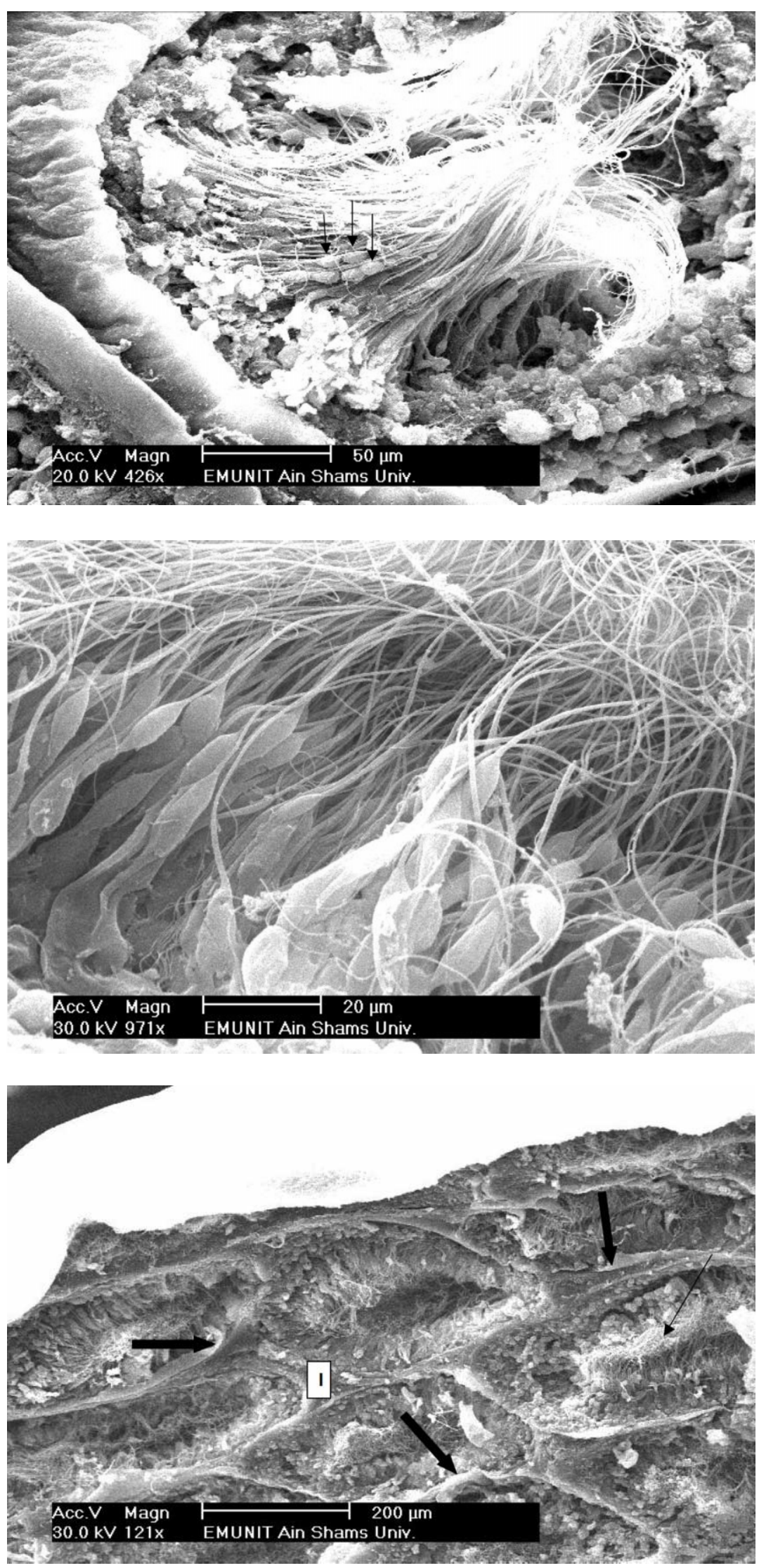

668
Fig. 2. Scanning electron micrograph of testicular sections of rats of the control group: shows mature spermatids completely occupying the lumina of the tubules (arrows) (SEM x 426).

Fig. 3. Scanning electron micrographs of testicular sections of rats of the control groups showing that each elongated spermatid exhibited an oval head and a single straight tail, of uniform thickness directed towards the lumen (SEM x 971).

Fig. 4. Scanning electron micrograph of testiicular sections of rats of the group II showing seminiferous tubules with slightly irregular outlines( thick arrows) and interstitial spaces (I) in between .The lumina of most of the seminiferous tubules were occupied by the spermatids ( thin arrow) (SEM x 121). 

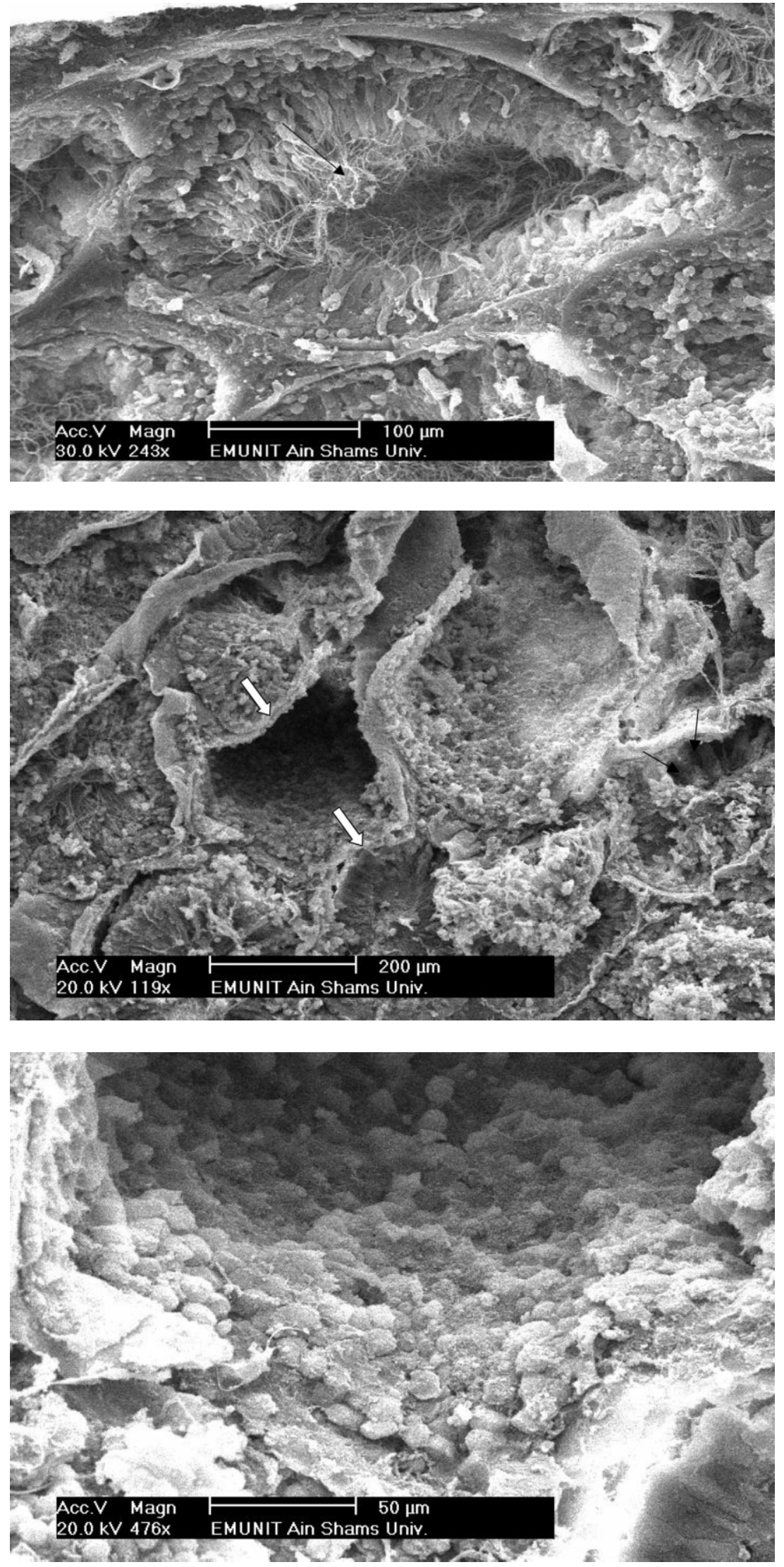

Fig. 5. Scanning electron micrograph of testicular sections of rats of the group II animal showing that most of the seminiferous tubules were occupied by mature elongated spermatids (arrow) (SEMX243).

Fig. 6. Scanning electron micrograph of the testicular section from group III animal showing compressed seminiferous tubules with wrinkled basement membrane (thick arrows). Some of tubules are appearing empty while others are occupied with spermatogenic cells (thin arrows)(SEM x 119).

Fig. 7. Scanning electron micrograph of the testicular sections from group III animal showing empty seminiferous tubule (SEM $\mathrm{x}$ 476). 


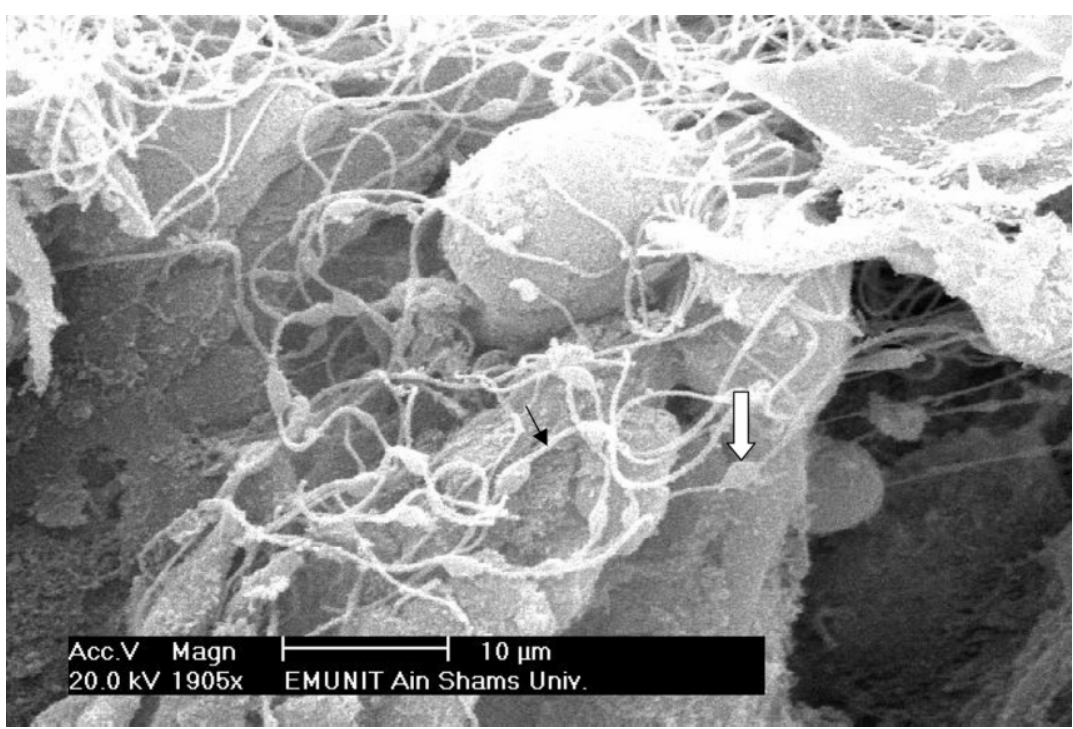

Fig. 8. Scanning electron micrograph of testicular sections of rats of the group III showing mature elongated spermatids with oval heads (thick arrow) and elongated straight tails (thin arrows) but of small sizes compared to the control group (SEM x 1905).

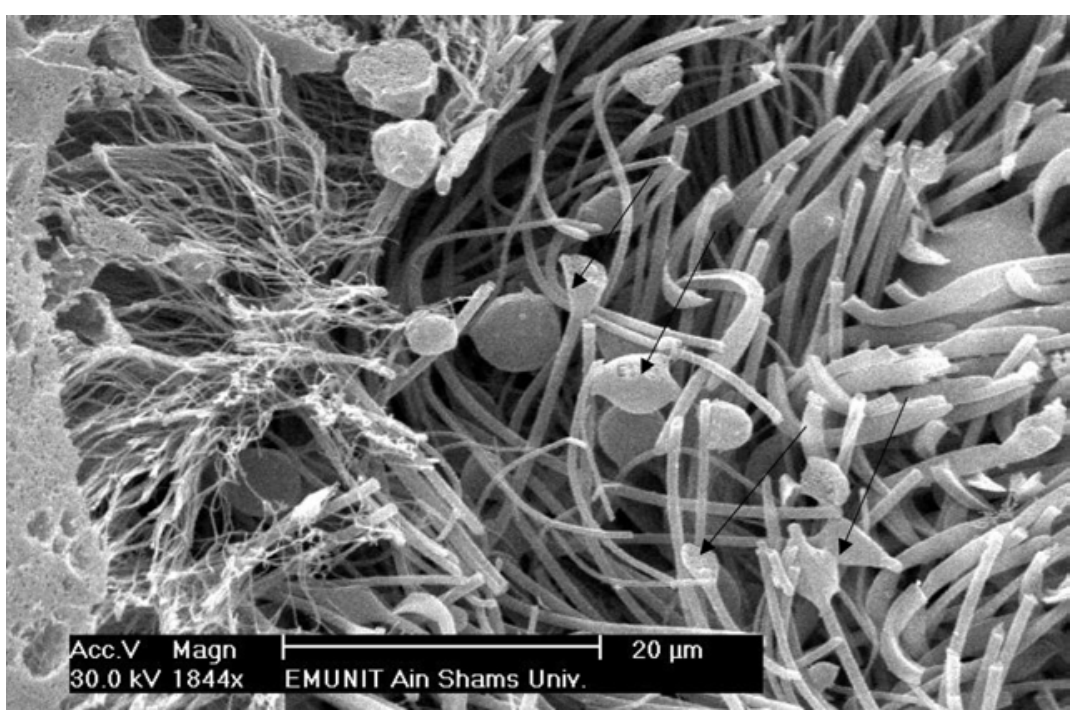

Fig. 9. Scanning electron micrograph of the testicular sections of group III showing abnormal forms of sperms (thin arrows) (SEM x 1844).

SEM sections of group III animals revealed that the majority of seminiferous tubules were compressed with wrinkled basement membrane (Fig.6). Most of tubules did not have any of the spermatogenic cells (Fig. 7). Intercellular spaces were observed in between the spermatogenic cells in few of the tubules (Figs. 6 and 7). The young spermatids appeared polymorphic in shape. There was an apparent decrease in number of mature spermatids as compared to the control group. Some had oval heads and elongated straight tails but of small sizes compared to the control group in spite of higher magnification (Fig. 8). Others exhibited abnormal forms (Fig. 9).

\section{DISCUSSION}

The present study showed that oral administration of RO in a dose of $250 \mathrm{mg} /$ $\mathrm{kg}$ body weight has little effect on the histology of the germ cells and testis while the oral administration in a dose of $500 \mathrm{mg} /$ $\mathrm{kg}$ body weight. revealed marked changes in the microscopic structure of the testis and germ cells

All cell types of the spermatogenic series were observed to be present in the seminiferous tubules of the animal treated at low dose. On the other hand, high dose administration of RO led to depletion of all cell types of the spermatogenic series and abnormal forms of the spermatids were also found to be present in the seminiferous tubules of these animals.

Nusier et al. have reported that after oral administration of RO in wistar rats, the testes of some of the animals were severely affected with degenerative changes in most of the germ cells and shrinkage of the seminiferous tubules while the others showed germ cell depletion with some areas of the seminiferous tubules were lined by sertoli cells only. Spermatogonia were hardly detected in any of the animals.

In the present study, the lumina of most of the seminiferous tubules after low dose administration were occupied by mature elongated spermatids .The basement membrane of the tubule appeared to have slightly irregular outlines. However, the seminiferous tubules of the animals treated with high dose appeared to be compressed and with very apparent marked irregular outlines.

The process of spermatogenesis and function of accessory reproductive organs are androgen dependent (Robinson et al.; Dym et al., 1979; Desjardins, 1978). Akinloye et al. (2002), in their study has suggested that decrease number of leydig cells in interstitial space is responsible for decrease production of testosterone known 
to be responsible for normal testicular architecture. These effects of RO at high dose in male rats may be because of various possibilities. The treatment may have resulted in a decrease in the pituitary hormones of spermatogenesis (Akinloye et al.). Lower LH and testosterone levels may result in delayed maturation of spermatozoa, or lower FSH levels may have affected the Sertoli cell function resulting in disturbed facilitatory function of these cells which are essential for the maturation and release of spermatozoa in the tubular lumen (Sadler, 1999). Nusier et al. have reported a significantly increased number of degenerating Leydig cells in the animals treated with RO, while the Present study has not shown any significant changes in the morphology or number of FSH dependent sertoli cells suggesting that if responsible, it is $\mathrm{LH}$ and not the FSH which has been affected by oral administration of RO at a higher dose in this study.

The present study has showed a dose dependent antifertility potential of the oral RO amongst male albino rats on oral administration.

Further studies are recommended to identify and isolate the active component(s) in RO that affect fertility in male rats and to determine its mechanism of action.

EL-DIN, R. A. S.; EL-SHAHAT, A. E. \& ELMANSY, R. A. Un estudio de microscopía electrónica del potencial anti-fertilidad del romero (Rosmarinus officinalis L.) en ratas macho albinas.Int. J. Morphol., 30(2):666-672, 2012.

RESUMEN: El trabajo tuvo como objetivo estudiar el potencial anti-fertilidad de la hierba de uso común, el romero, en ratas albinas macho utilizando microscopía electrónica como método de investigación. El extracto etanólico del romero se preparó y administró por vía oral a los animales en dos dosis diferentes durante un período de tres meses. Los animales experimentales se sacrificaron y se retiraron sus testículos. Se prepararon secciones para microscopía electrónica y se observaron los cambios. Los resultados mostraron cambios microscópicos evidentes en los testículos de los animales que recibieron una dosis mayor del medicamento. La mayoría de los túbulos seminíferos se observaron comprimidos, con una membrana basal irregular y carente de células espermatogénicas. El presente trabajo revela una clara evidencia morfológica de una posible anti-fertilidad dependiente de la dosis del romero administrada en las ratas albinas macho.

PALABRAS CLAVE: Potencial anti-fertilidad; Romero, Rosmarinus officinalis L.; Microscopía electrónica; Ratas macho albinas.

\section{REFERENCES}

Akinloye, A. K.; Abatan, M. O.; Alaka, O. O. \& Oke, B. O. Histomorphometric and histopathological studies on the effect of Calotropis procera (giant milkweed) on the male reproductive organs of wistar rats. African J. Biomed. Res., 5(1-2):57-61, 2002.

Amin, A. \& Hamza, A. A. Hepatoprotective effects of Hibiscus, Rosmarinus and Salvia on azathioprine-induced toxicity in rats. Life Sci., 77(3):266-78,, 2005.

Amin, A. \& Hamza, A. Effects of ginger and roselle on cisplatininduced reproductive toxicity in rats. Asian J. Androl., 8(5):60712, 2006.

Desjardins, C. Endocrine regulation of reproductive development and function in the male. J. Anim. Sci., 47(Suppl 2):56-79, 1978.

Dym, M.; Raj, H. G.; Lin, Y. C.; Chemes, H. E.; Kotite, N. J.; Nayfeh, S. N. \& French, F. S. Is FSH required for maintenance of spermatogenesis in adult rats? J. Reprod. Fertil. Suppl., (26):175-81, 1979.

Herrero, M.; Arraez-Roman, D.; Segura, A.; Kenndler, E.; Giusr, B.; Raggid, M. A.; Ibanez, E. \& Cifuentes, A. Pressurized liquid extraction-capillary electrophoresis-mass spectrometry for the analysis of polar antioxidants in rosemary extracts. $J$. Chromatogr. A, 1084(1-2):54-62, 2005.

Katerinopoulos, H. E.; Pagona, G.; Afratis, A.; Stratigakis, N. \& Roditakis, N. Composition and insect attracting activity of the essential oil of Rosmarinus officinalis. J. Chem. Ecol., 31(1):111-22, 2005.

Liu, C.; Wang, J. M.; Chu, C. Y.; Cheng, M. T. \& Tseng, T. H. In vivo protective effect of protocatechuic acid on tert-butyl hydroperoxide-induced rat hepatotoxicity. Food Chem. Toxicol., 40(5):635-41, 2002

Makino, T.; Ono, T.; Liu, N.; Nakamura, T.; Muso, E. \& Honda, G. Suppressive effects of rosmarinic acidon mesangioproliferative glomerulonephritis in rats. Nephron, 92(4):898-904, 2002.

Nusier, M. K.; Bataineh, H. N. \& Daradkah, H. M. Adverse effects of rosemary (Rosmarinus officinalis $\mathrm{L}$.) on reproductive function in adult male rats. Exp. Biol. Med., 232(6):809-13, 2007.

Prenesti, E.; Berto, S.; Daniele, P. G. \& Toso, S. Antioxidant power quantification of decoction and cold infusions of Hibiscus sabdariffa flowers. Food Chem., 100:433-8, 2007. 
Purohit, A. \& Daradka, H. M. Effect of mild hyperlipidaemia on testicular cell population dynamics in albino rats. Indian $J$. Exp. Biol., 37(4):396-8, 1999.

Ramírez, P.; Señoráns, F. J.; Ibanez, E. \& Reglero, G. Separation of rosemary antioxidant compounds by supercritical fluid chromatography on coated packed capillary columns. $J$. Chromatogr. A, 1057(1-2):241-5, ,2004.

Robinson, D. G.; Uhlers, V.; Herken, R.; Herrmann, B.; Mayer, F. \& Schurmann, F. W. Methods of preparation for electron microscope. Berlin, New York, Springer-Verlag, 1987. pp.23$66,148-64$.

Sadler, T. W. Gametogenesis. Langman's Medical Embryology. 8a ed. Baltimore, William \& Willkins, 1999.

Tsai, P. J. \& Huang, H. P. Effect of polymerization on the antioxidant capacity of anthocyanins in Roselle. Food Res. Intern., 37:3138, 2004.

Tseng, T.; Kao, E. S.; Chu, C. Y.; Chou, F. P.; Lin Wu, H. W. \& Wang, C. J. Protective effects of dried flower extracts of Hibiscus sabdariffa L. against oxidative stress in rat primary hepatocytes. Food Chem. Toxicol., 35(12):1159-64, 1997.

Valenzuela, A.; Sanhueza, J.; Alonso, P.; Corbari, A. \& Nieto, S. Inhibitory action of conventional food-grade natural antioxidants and of natural antioxidants of new development on the thermal-induced oxidation of cholesterol. Int. J. Food Sci. Nutr., 55(2):155-62, 2004.

Wang, C.; Wang, J. M.; Lin, W. L.; Chu, C. Y.; Chou, F. P. \& Tseng, T. H. Protective effect of hisbiscus anthocyanins against tertbutyl hydroperoxide-induced hepatic toxicity in rats. Food Chem. Toxicol., 38(5):411-6, 2000.

Working, P. K.; Bus, J. S. \& Hamm, T. E. Jr. Reproductive effects of inhaled methyl chloride in the male Fischer 344 rat. II. Spermatogonial toxicity and sperm quality. Toxicol. Appl. Pharmacol., 77(1):144-57, 1985.

\section{Correspondence to: Abd-El Rahman Shahat, MD. Department of Anatomy Faculty of Medicine Cairo University EGYPT}

\section{Email:shaikhm.63@gmail.com khalielabdulrahman@yahoo.com}

Received: 17-10-2011

Accepted: 11-01-2012 